\title{
Commodity prices, credit cycles, and consumption in Russia, Ukraine, and Belarus
}

\author{
Scott W. Hegerty \\ Department of Economics, \\ Northeastern Illinois University, \\ United States \\ S-Hegerty@neiu.edu
}

\begin{abstract}
From the 1990s to the onset of the 2008 crisis, consumer credit in former socialist economies expanded dramatically. While this "bubble" has since been reduced, there nonetheless remains the potential for new ones to form. Russia, where oil and commodity prices help drive capital inflows, the government budget, household consumption, and the overall economy, has not received as much attention as the Central and Eastern European countries that have joined the European Union. Nor have its smaller, energy-dependent neighbours of Ukraine and Belarus. This study fills this gap by examining the connections between domestic credit, consumption, and commodity prices in these three countries using quarterly time-series data from 1996 to 2017. After extracting filtered cycles and examining correlations, Vector Autoregressive methods are used to uncover the direction of causality among credit growth and a set of macroeconomic variables. There is little evidence of linkages between domestic credit and consumption in any country, but inflation and credit growth are linked in all countries. Rising commodity prices reduce credit growth in Russia and perhaps Belarus, which has been subject to severe economic sanctions in recent years. Consumers appear to be rather insulated from drops in commodity prices, however, which might help reduce pressure on their governments to deliver policy reforms.
\end{abstract}

Keywords: domestic credit, capital flows, consumption, Russia, time series.

JEL Classification: F41, E51

\section{INTRODUCTION}

In the decades since the collapse of the Soviet command economy, consumer credit has expanded greatly in the region. Where there had once been a shortage of goods and an excess of cash, consumers are now enticed to purchase products immediately - often after borrowing the money effortlessly using a smartphone app. Lending for home or other purchases has expanded as well. Credit expansion is closely 
connected to the overall economy and therefore can follow a cyclical pattern similar to GDP. In particular, the credit collapse of 2008 both caused, and was affected by, an overall economic downturn. Additionally, much of this credit expansion was fuelled by capital inflows, but as geopolitical conditions changed (which was shown after Russia's 2014 invasion of Ukraine), these flows can quickly dry up, and consumer credit and spending can suffer as a result. Consumer credit and spending are also sensitive to the prices of oil and other commodities, which serve as a key source of revenue in Russia and other commodity exporters. Price declines might, therefore, lead to a credit decrease, but on the other hand, consumption smoothing might lead to countercyclical behaviour, whereby people borrow to maintain a steady level of consumption. Credit expansion might also might help make up for reductions in government revenue. These effects are therefore ambiguous and needs to be tested empirically.

Evaluating credit cycles - in a manner similar to the macroeconomic analysis of business cycles - will yield important information about the behaviour of consumer credit in the countries of Eastern Europe. Given the array of internal and external factors that affect lending in the region, including the ongoing transition to fully developed consumer capitalism and the development of a robust banking system capable of accommodating this economic system, one can see how credit has behaved over the past two decades. This is particularly important for Russia, Ukraine, and Belarus, which have received considerably less attention than those neighbours that have already joined the European Union, but which are more directly tied to fluctuations in commodity prices.

These countries have diverged considerably in terms of their degree of transition, political reforms, and dependence on energy exports or imports. One may argue that Belarus' economy has reformed the least, while Russia's version of "state capitalism" outperforms Ukraine's economy. Yet Ukraine's peaceful transition of power following the 2019 presidential election reflects positively compared to Aleksandr Lukashenka's continuing presidency of Belarus, which began before this study begins, or Vladimir Putin's uninterrupted tenure as President or Prime Minister of Russia. Russia's role as an energy exporter allows it to maintain influence on its smaller, energy-importing neighbours, but this also makes the country's budget and financial vulnerable to declines in global energy prices.

One can expect variation in these results, which might have important geopolitical implications. In particular, if commodity-price declines precede a credit crunch, the resulting impact on households might put pressure on leaders at home. This dynamic can differ from that which takes place in neighbours to the West, which share similar past economic systems but are now more closely integrated with the economies and democratic processes of the European Union. While they diverge from one another, the three countries studied here share even greater disparities with Central Europe, which has been the subject of many more studies on the topic. There is therefore a need to examine the interlocking effects on these three economies.

Having determined these countries' credit cycles, they can be used to answer two key research questions: What macroeconomic variables drive domestic credit in these countries, and how do changes in credit affect domestic consumption and the rest of the economy? Fluctuations in credit can be compared against similar cycles in output and domestic consumption, as well as in commodity prices, to show not only how commodity prices and capital flows might relate to domestic credit and consumption, but also whether consumption smoothing might occur.

This method of analysis, however, does not allow for any conclusions regarding causation. This study therefore also examines the connections between capital inflows (proxied by the current account), domestic credit growth, domestic consumption (as a percentage of GDP), and commodity prices for Russia, Ukraine, and Belarus. These three economies are also expected to behave differently from their economically and politically distinct neighbours. Russia is a major oil exporter, which has allowed it to run 
large current account surpluses, and its two smaller neighbours are closely tied to its economy, and its energy exports in particular.

In this study, two main methods of analysis are applied: First, the cyclical components of our main variables are extracted and cross-correlation functions are calculated to see whether credit, consumption, and capital flows "lead" or "lag" one another. Second, Vector Autoregressive (VAR) methods are used to test for spillovers among these and other macroeconomic variables, paying particular attention to responses to shocks from and to domestic credit growth. Our main findings are that domestic credit is shown to be linked to consumption in Russia, but not Ukraine or Belarus. Commodity prices have the clearest effects on Russian credit growth as well. In addition, inflation and credit growth drive each other in a way that suggests that declining purchasing power reduces credit growth.

\section{LITERATURE REVIEW}

In general, a country's current account deficit increases if its domestic absorption (Consumption plus Investment and Government spending) exceeds its overall level of production. Since these deficits are often financed through financial transactions, a link from capital inflows directly to consumption can be expected. At the same time, the banking system can play an intermediary role in this process, as capital inflows lead to increases in domestic credit, which can likewise drive consumption. If these flows are tied to commodity prices, one would expect direct linkages between these prices and consumption, particularly through the domestic credit channel. Statistical analysis can uncover the exact processes through which this takes place.

Previous studies that focus on Central Europe rather than Russia, Ukraine or Belarus include Hoffmann (2010), who examines credit cycles in Poland, Estonia, and Romania in a heterodox fashion; Lane and Milesi-Ferretti (2007), who focus on the composition of capital flows; Park (2014), who studies comovements between capital inflows and business cycles in emerging economies including Europe; and Lane and McQuade (2014), who prefer to use net debt flows rather than the current account as a proxy for capital flows. Staehr (2018) uses panel methods on annual data for the 11 Central and Eastern European (CEE) EU members, concluding that improvements in the current account balance can have a detrimental impact on GDP growth. Vymyatnina and Antonova (2014) offer one of the few studies to focus on linkages between domestic credit and macroeconomic variables in the Eurasian Economic Union members of Russia, Belarus, and Kazakhstan.

Capital flows, macroeconomic variables such as GDP growth, inflation, and domestic credit are also shown to interact with and mutually influence one another. Few studies include all variables, however. Lankes and Venables (1996), Gibson and Tsakalotos (2004), Carstensen and Taubal (2004), and Demekas et al. (2007) include certain combinations of macroeconomic variables in their models of foreign investment and capital flows as the variable of interest. Examining the determinants of domestic credit, Gueorguiev et al. (2005) conclude that capital flows help drive credit growth in Ukraine, while Égert et al. (2007) show that GDP per capita plays a role in eight CEE countries, and Allegret and Sallenave (2015) examine capital inflows and credit "booms" in nine CEE economies. Domestic credit can also serve as an explanatory variable in these models: Lane and Milesi-Ferretti (2010) find that both current account deficits and the ratio of private credit to GDP helped explain the intensity of the 2008 crisis in the region, and Apostoaie et al. (2014) examine correlations and Granger causality to find linkages between domestic credit and economic growth in Poland and Romania. In one of the few studies that evaluate multiple countries individually, Hegerty (2009) conducts a Vector Autoregression (VAR) analysis of the fixed-rate regimes of Bulgaria and the Baltics and finds that capital inflows drive credit growth only in Bulgaria. 
While capital flows serve as a proxy for the commodity prices that drive them, few studies enter this model into their models directly. Kalyuzhnova and Nygaard (2009) do so, examining the linkages from energy prices to domestic credit through the prism of "resource nationalism," and finding that increased hydrocarbon prices do indeed drive credit booms. An expansion of this line of analysis, combined with those of the preceding literature, is a key objective here.

This study combines cyclical and VAR analysis to examine the linkages among domestic credit, commodity prices, and domestic consumption, as well as the current account and other macroeconomic variables. It proceeds as follows. Section 3 describes the methodology. Section 4 discusses the results. Section 5 concludes.

\section{METHODOLOGY}

Theoretically, we rely on a simple macroeconomic model based on Kydland and Prescott (1982) and Backus et al. (1992), which show that time lags are required for capital adjustment and the comovement among macroeconomic variables. This study assumes a similar process, not only between consumption and output, but between commodity prices and these two variables. Fluctuations in these prices are expected to spill over to the real economy, but only after an adjustment lag. In particular, increased input costs might pass through to product prices slowly; borrowing costs might also take time to adjust after commodity-price fluctuations affect domestic interest rates and exchange rates. Our method of analysis captures both the presence of these spillovers, as well as their time path.

This study uses quarterly time-series data in an analysis of credit cycles and the interactions among credit growth and a set of key macroeconomic variables. For the former, time-series analysis is applied to extract the cyclical component from each country's real domestic credit (as a share of GDP), as well as real GDP and consumption (also as a share of GDP). This study does the same for Brent oil prices and a measure of commodity prices. While the Hodrick-Prescott (1997) filter is well-known and widely used, it is often criticized for its treatment of the underlying statistical processes (See Hamilton, 2017, for example), the method of Christiano and Fitzgerald (1999) is used instead in this study. All calculations are conducted in the $\mathrm{R}$ software environment, except for the Generalized Impulse Response Functions described below, which are performed in EViews.

Each filtered credit, output, and consumption cycle is then plotted, as well as a single commodityprice cycle, to examine trends visually before calculating cross-correlation functions to assess the degree of synchronization between macroeconomic variables. Following Hegerty (2010), the CCF is calculated as follows:

$$
\rho_{t+k}=\frac{\sum\left(X_{t}-\bar{X}\right)\left(Y_{t+k}-\bar{Y}\right)}{\sqrt{\sum\left(X_{t}-\bar{X}\right)^{2} \sum\left(Y_{t+k}-\bar{Y}\right)^{2}}}
$$

"Contemporaneous" correlation occurs where $\mathrm{k}=0$. If $\mathrm{k}>0, \mathrm{X}$ in a previous period is correlated with $\mathrm{Y}$ in the current period, or $\mathrm{X}$ "leads" $\mathrm{Y}$. Likewise, for values of $\mathrm{k}<0, \mathrm{X}$ in the current period is correlated with $\mathrm{Y}$ in a previous period, so $\mathrm{X}$ "lags" $\mathrm{Y}$. With quarterly data, these are computed over the range $\mathrm{k}=[-4,4]$ for each pair. Cycles are considered to be synchronized if the highest value of $\varrho$ is found where $\mathrm{k}=0$. But it could be meaningful of one cycle is shown to lead another, for example, if domestic credit leads or lags consumption. Pairs where this relationship is particularly strong are noted. 
In the second part of our analysis, sets of stationary variables are entered into a VAR to examine the impact of shocks. We difference as necessary based on the results of the Phillips-Perron (1988) stationarity test. Based on the abovementioned literature, our vectors contain the following variables:

$$
\text { [CRG, CASHARE, CSHARE, DLNPC, DLNREER, GROWTH, INF] }
$$

Growth rates are calculated as quarter-on-quarter percentage changes. It may be expected that each variable might affect the others; in particular, commodity prices, consumption booms or current-account deficits might fuel credit growth, while domestic credit could drive real appreciations, international borrowing, or increased consumption. Our empirical tests will help shed light on which economic forces are strongest.

Granger causality/block exogeneity tests isolate the determinants of all variables, and report full results for the determinants of CRG, as well as credit growth's contribution to the other main variables, to see whether the incorporation of an additional variable helps the explanatory power of a time-series regression. Impulse responses, which calculate the effects of a one-standard deviation shock to the VAR error term, are then conducted using the Generalized VAR methodology of Pesaran and Shin (1998), which is invariant to the ordering of the variables. In the interest of space, only the responses involving credit growth (both as a source and in response to shocks) are provided. Overall, the Granger causality tests provide the most useful information, because the Impulse-Response Functions generated using VAR methods are often ambiguous.

\section{EMPIRICAL RESULTS AND DISCUSSION}

Most data are taken from the International Financial Statistics of the International Monetary Fund for this analysis. They are quarterly and span the period from 1996q1 to 2017q3. Ukrainian data are more limited, beginning in 2000 and ending in 2016. The commodity-price data are taken from the St. Louis Federal Reserve Economic Data (FRED) database, and Belarus' Central Bank data are used for the country's real effective exchange rate (REER). While both oil prices (U.K. Brent) and a commodity-price index are considered, Figure 1 shows that the two series are highly correlated. The composite index, therefore, is used for the remainder of this study.

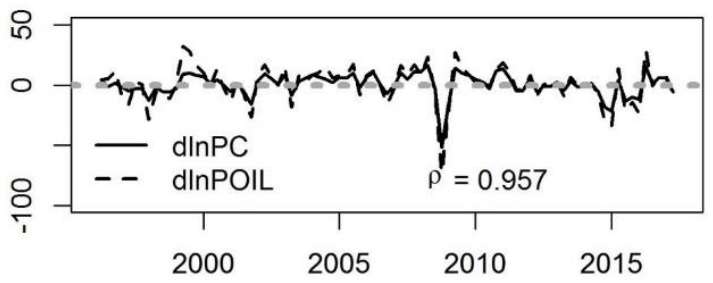

Figure 1. Oil and Commodity Prices (Log Changes), 1996-2017

Domestic Credit (\% of GDP)

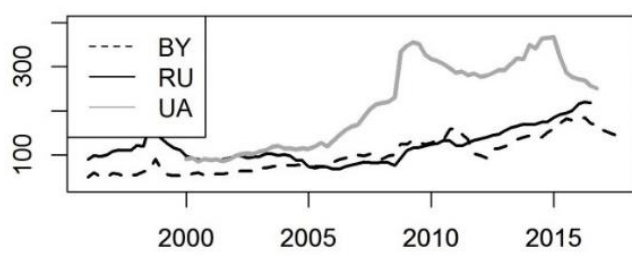

Current Account (\% of GDP)

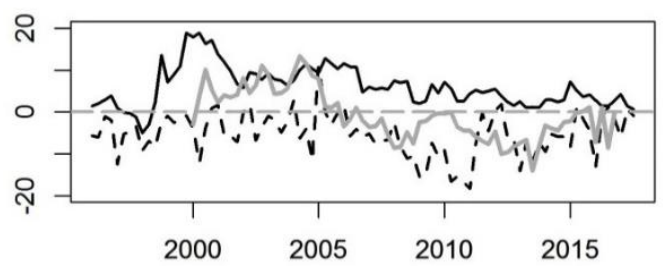

Figure 2. Domestic Credit and Current Accounts, 1996-2017 
The time-series behaviour of our main macroeconomic variables is assessed first. Figure 2 depicts all three countries' domestic credit and current account as shares of GDP. While all are increasing, Ukraine experienced a "boom" (with domestic credit exceeding 300 percent of GDP), followed by a bust, leading up to 2014. Of the three current accounts, only Russia's has been consistently in surplus. Belarus' deficit was quite large (20 percent of GDP) following the 2008 global financial crisis. Figure 3 depicts household consumption, both in (real) levels and as percentages of GDP, and commodity prices on both levels and in $\log$ changes. There is a similar "boom-bust" pattern, both before and after the 2008 financial crisis, in both variables. Since these patterns might be driven by domestic as well as international factors, and involve potentially ambiguous connections among the variables, this study next examines crosscorrelations between each pair. Figure 4 depicts the filtered cyclical components of the main macroeconomic variables. The 2008 downturn is clearly visible.

Table 1 presents pairwise cross-correlation functions among domestic credit, consumption, and output cycles for all three countries, as well as between domestic credit and commodity-price cycles, at up to four leads and lags. If synchronization is indicated when a CCF's highest value is found at zero leads and lags, only consumption and output are considered to be synchronized. Domestic credit is often negatively correlated with both output and consumption, but positive correlations at $\mathrm{k} \geq 1$ suggest that domestic credit "lags" consumption, particularly in Belarus and Ukraine. Credit might also lag output in Ukraine, indicating that rapid growth in lending, depicted in Figure 1, was driven by real events in the overall economy and may, in fact, be countercyclical. Economic "booms" might increase credit growth, but only at such a lag that they are felt after the boom subsides.

Belarus

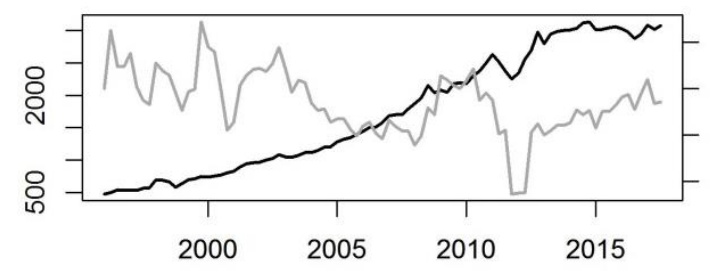

Ukraine

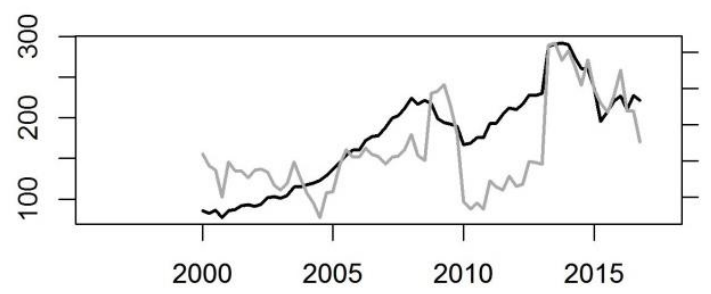

Russia

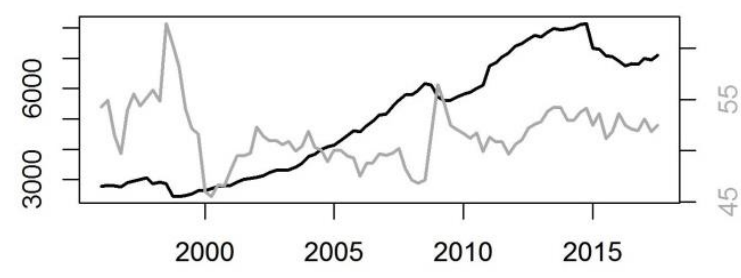

Commodity Prices

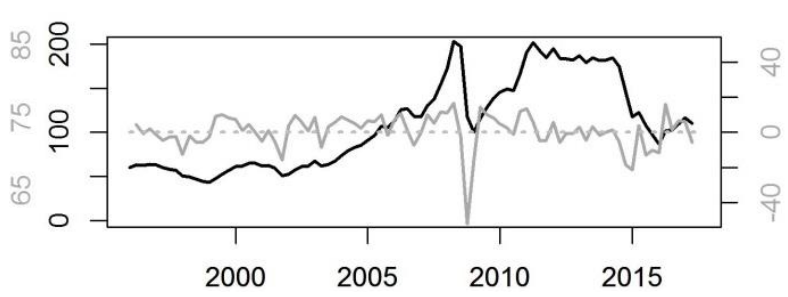

Figure 3. Consumption and Commodity Prices, 1996-2017

Country graphs (Consumption): Black line/left scale $=$ real values; Grey line $/$ right scale $=$ share of GDP. Commodity price graph: Levels in black, percentage changes in grey. 
Consumption Cycles

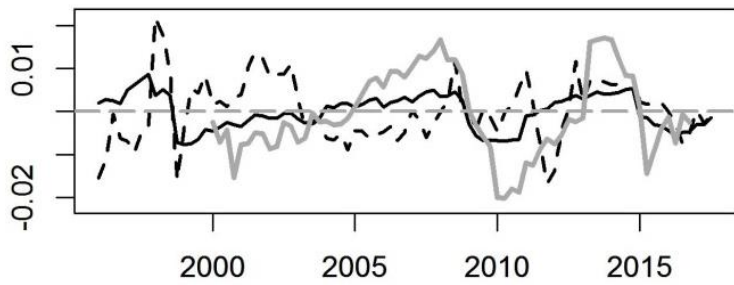

Output Cycles

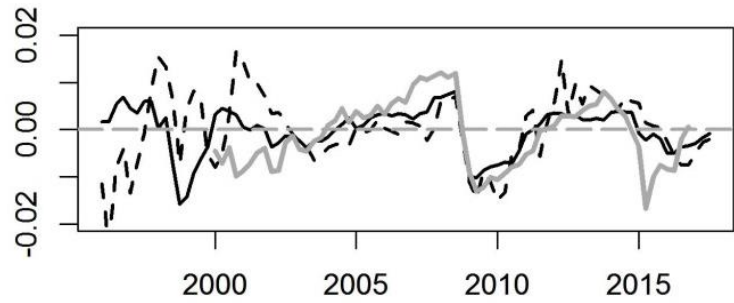

Credit Cycles
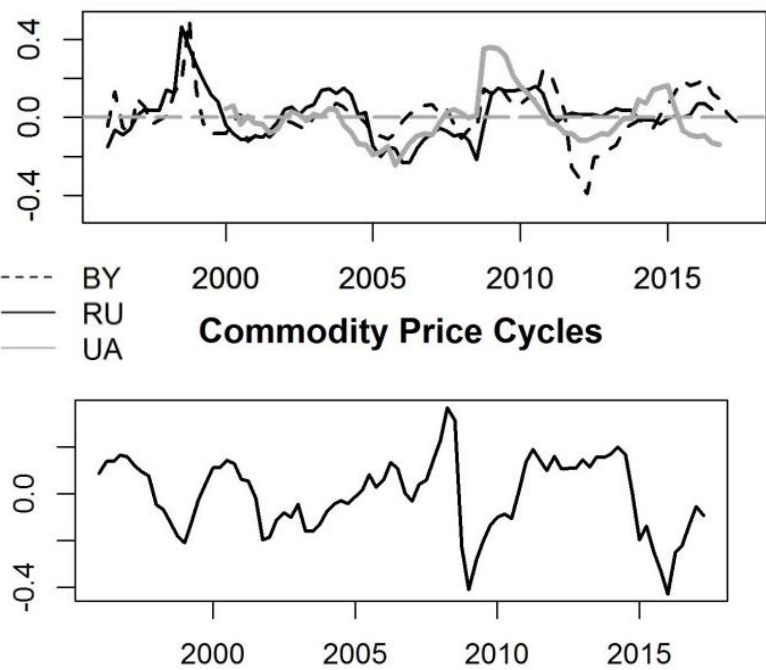

Figure 4. Christiano-Fitzgerald Filtered Cycles

Overall, domestic credit exhibits an "S-curve" pattern, with negative correlations in "lead" quarters and positive correlations in quarters where credit growth "lags" consumption (for all three countries). Similar patterns are shown for domestic credit vis-à-vis output and commodity prices for Ukraine only. As might be expected, consumption and output are highly synchronized, with high positive correlations for all three countries. Belarus' highest value is 0.567 at zero lags, Russia's is 0.823 at one lead, and Ukraine's is 0.814 at zero lags. Domestic credit behaves countercyclically with respect to output and commodity prices for both Belarus and Russia; all values are either negative or close to zero.

Table 1

Cross-Correlation Functions

\begin{tabular}{|r|c|c|c|c|c|c|}
\hline & \multicolumn{3}{|c|}{ Domestic Credit/Consumption } & \multicolumn{3}{c|}{ Consumption/Output } \\
\hline Leads/lags & $\mathbf{B Y}$ & $\mathbf{R U}$ & $\mathbf{U A}$ & $\mathbf{B Y}$ & $\mathbf{R U}$ & UA \\
\hline-4 & -0.242 & -0.362 & $\mathbf{- 0 . 6 7 8}$ & 0.078 & -0.023 & 0.138 \\
\hline-3 & -0.279 & -0.420 & -0.582 & -0.052 & 0.177 & 0.326 \\
\hline-2 & -0.297 & -0.472 & -0.451 & 0.003 & 0.376 & 0.496 \\
\hline-1 & -0.164 & $-\mathbf{0 . 5 1 1}$ & -0.276 & 0.300 & 0.593 & 0.660 \\
\hline 0 & -0.066 & -0.410 & -0.074 & $\mathbf{0 . 5 6 7}$ & 0.794 & $\mathbf{0 . 8 1 4}$ \\
\hline 1 & 0.205 & -0.255 & 0.134 & 0.507 & $\mathbf{0 . 8 2 3}$ & 0.809 \\
\hline 2 & $\mathbf{0 . 3 5 8}$ & -0.128 & 0.288 & 0.399 & 0.720 & 0.778 \\
\hline 3 & 0.308 & 0.022 & 0.431 & 0.250 & 0.597 & 0.741 \\
\hline 4 & 0.050 & 0.132 & 0.510 & 0.171 & 0.433 & 0.675 \\
\hline & \multicolumn{7}{|c|}{ Domestic Credit/Output } & & Domestic Credit/PC \\
\hline Leads/lags & BY & RU & UA & BY & RU & UA \\
\hline-4 & -0.275 & -0.218 & $-\mathbf{0 . 6 2 3}$ & -0.079 & 0.087 & -0.349 \\
\hline-3 & -0.271 & -0.380 & -0.609 & -0.191 & 0.021 & -0.314 \\
\hline
\end{tabular}




\begin{tabular}{|r|c|c|c|c|c|c|}
\hline-2 & -0.311 & -0.546 & -0.576 & -0.323 & -0.112 & -0.303 \\
\hline-1 & -0.344 & -0.701 & -0.512 & -0.460 & -0.312 & $\mathbf{- 0 . 3 3 0}$ \\
\hline 0 & $\mathbf{- 0 . 4 4 2}$ & $\mathbf{- 0 . 7 4 3}$ & -0.382 & $\mathbf{- 0 . 5 5 2}$ & -0.529 & -0.305 \\
\hline 1 & -0.223 & -0.588 & -0.135 & -0.534 & $\mathbf{- 0 . 5 6 7}$ & -0.162 \\
\hline 2 & -0.063 & -0.417 & 0.065 & -0.445 & -0.456 & 0.022 \\
\hline 3 & -0.038 & -0.221 & 0.229 & -0.323 & -0.308 & 0.152 \\
\hline 4 & -0.068 & -0.036 & 0.350 & -0.206 & -0.193 & 0.236 \\
\hline
\end{tabular}

First variable "leads" the second variable at $k<0$ and "lags" at $k>0$. Bold $=$ highest (absolute value) correlation.

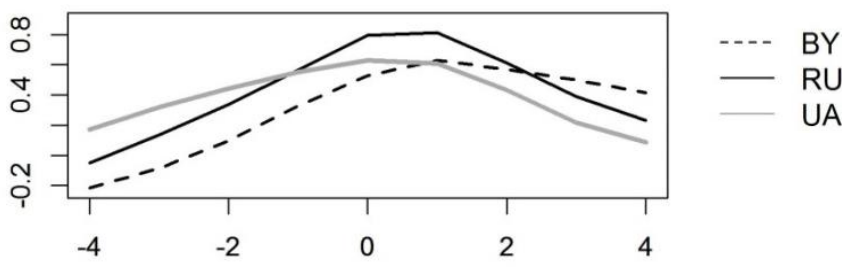

Figure 5. Cross-Correlation Functions: Output and Commodity-Price Cycles

Figure 5 shows cross-correlations, graphically, between output and commodity prices. Values are quite high (particularly Russia's value of 0.815 at zero lags, which indicates synchronization). Belarus shows more evidence of time lags (its largest value is 0.630 at one quarter), while Ukraine's correlations are lower, but synchronized ( 0.628 at zero lags). While these cross-correlations show interesting bivariate connections, their underlying causes of these relationships are left uncovered by this methodology.

This study therefore next examines causal relationships, in terms of both the determinants of credit growth and the influence of domestic credit on the other macroeconomic variables. This is done in a Generalized VAR framework, with all stationary variables, and with growth rates entered instead of cycles. Based on the results provided in Table 2, only the small number of variables (such as the Russian current account and Ukrainian consumption) with p-values greater than at 10 percent are differenced. We choose a VAR lag length by minimizing the Schwarz Criterion; the selected length is generally one.

Table 2

Phillips-Perron Stationarity Test Results

\begin{tabular}{|l|c|c|c|c|c|c|}
\hline & Belarus & & Russia & & Ukraine & \\
\hline & Level & 1st Diff. & Level & 1st Diff. & Level & 1st Diff. \\
\hline Variable & Stat (p-val.) & Stat (p-val.) & Stat (p-val.) & Stat (p-val.) & Stat (p-val.) & Stat (p-val.) \\
\hline CASHARE & $-5.456(0.010)$ & $-14.704(0.010)$ & $-2.758(0.265)$ & $-9.348(0.010)$ & $-3.265(0.085)$ & $-12.101(0.010)$ \\
\hline GROWTH & $-3.664(0.033)$ & $-10.759(0.010)$ & $-5.176(0.010)$ & $-11.025(0.010)$ & $-5.229(0.010)$ & $-11.915(0.010)$ \\
\hline INF & $-3.429(0.057)$ & $-8.453(0.010)$ & $-4.417(0.010)$ & $-7.808(0.010)$ & $-5.381(0.010)$ & $-12.205(0.010)$ \\
\hline CRG & $-8.054(0.010)$ & $-16.898(0.010)$ & $-7.846(0.010)$ & $-18.012(0.010)$ & $-6.388(0.010)$ & $-15.712(0.010)$ \\
\hline DLNREER & $-7.361(0.010)$ & $-13.466(0.010)$ & $-7.705(0.010)$ & $-17.281(0.010)$ & $-6.962(0.010)$ & $-13.917(0.010)$ \\
\hline DLNPC & $-6.079(0.010)$ & $-11.742(0.010)$ & $-6.105(0.010)$ & $-11.800(0.010)$ & $-5.640(0.010)$ & $-10.803(0.010)$ \\
\hline CSHARE & $-3.405(0.061)$ & $-8.989(0.010)$ & $-3.203(0.093)$ & $-8.543(0.010)$ & $-2.950(0.189)$ & $-7.847(0.010)$ \\
\hline
\end{tabular}


One important finding is that credit growth has no relationship with either consumption or the current account. Commodity prices, on the other hand, Granger-cause credit growth in Belarus and Russia. Inflation also Granger-causes credit growth in all countries, making it the most consistent of all macroeconomic determinants. Since credit growth also Granger-causes inflation, it is possible that a "vicious" cycle might result, whereby inflation and expanded credit fuel a bubble. This would require knowledge of the signs of the effects, which is not provided by this test, but the Impulse Response Functions below, however, show that the negative response of credit growth to a shock to inflation suggests a "dampening" effect instead.

It is also expected that increased commodity prices will raise costs for households and businesses, but only the IRFs will be able to show whether this leads to a credit crunch, or whether lending increases to counteract these price increases. Likewise, high commodity prices might affect consumer prices differently for commodity exporters and importers. GDP growth and changes in the log real effective exchange rate also have significant effects on domestic credit growth in Belarus. These two variables are affected in the other direction of causality, in Belarus as well as in Russia. Credit growth Granger-causes inflation in Russia and Ukraine. Overall, Belarus has the most variables linked to credit growth and Ukraine the least. Again, consumption and the current account are unaffected.

The preliminary Granger causality tests can show the presence of economic relationships, but not the direction. These results are provided in Table 3. Here, the sole focus is on significance (p-value less than 0.05), rather than the coefficient value. Belarus has the most significant contributors to credit growth and Ukraine the least; credit growth in turn primarily affects growth or inflation in the three countries.

In order to capture the direction of causality, the Generalized Impulse Response Functions (GIRFs) that involve CRG are plotted in Figure 6. Often, however, the results are ambiguous. There are a number of interesting unidirectional, as well as bidirectional, responses, however. This is particularly true for responses involving the current account and the consumption share.

Table 3

Granger Causality/Block Exogeneity Test Results

\begin{tabular}{|c|c|c|c|c|c|c|c|}
\hline \multicolumn{4}{|c|}{ Contributors to CRG: } & \multicolumn{4}{|c|}{ CRG contributions to: } \\
\hline & Belarus & Russia & Ukraine & & Belarus & Russia & Ukraine \\
\hline Variable & Coeff. (p-val.) & Coeff. (p-val.) & Coeff. (p-val.) & Variable & Coeff. (p-val.) & Coeff. (p-val.) & Coeff. (p-val.) \\
\hline CASHARE & $0.106(0.745)$ & $0.382(0.536)$ & $0.300(0.584)$ & CASHARE & $0.010(0.922)$ & $3.425(0.064)$ & $0.605(0.437)$ \\
\hline CSHARE & $3.398(0.065)$ & $0.545(0.461)$ & $0.003(0.959)$ & CSHARE & $1.055(0.304)$ & $0.067(0.796)$ & $0.769(0.380)$ \\
\hline DLNREER & $5.863(0.016)$ & $0.097(0.755)$ & $0.653(0.419)$ & DLNREER & $8.886(0.003)$ & $9.644(0.002)$ & $0.220(0.639)$ \\
\hline GROWTH & $5.290(0.021)$ & $0.610(0.435)$ & $3.825(0.051)$ & GROWTH & $17.918(0.000)$ & $7.505(0.006)$ & $2.130(0.144)$ \\
\hline INF & $17.270(0.000)$ & $4.890(0.027)$ & $6.661(0.010)$ & INF & $2.486(0.115)$ & $17.23(0.000)$ & $4.387(0.036)$ \\
\hline DLNPC & $4.209(0.040)$ & $7.313(0.007)$ & $0.440(0.507)$ & & & & \\
\hline All & $34.202(0.000)$ & $27.495(0.000)$ & $9.404(0.152)$ & & & & \\
\hline
\end{tabular}

Bold $=$ Significant at 5 percent. Direction of causality indicated by significant coefficients. Mutual causality is shown when both causation to credit growth and causation from credit growth are both significant at 5 percent when both are significant. Causation to commodity prices is are expected to be affected by global factors, not by credit growth in these countries.

In Belarus, for example, shocks to credit growth and changes in the log real effective exchange rate have negative effects on each other. This could lead to a feedback cycle whereby increased credit growth drives a real depreciation, which then serves to increase credit growth further. Both variables were shown 
to be significant in the Granger causality tests as well. Positive shocks to $C R G$ also have negative effects on GDP growth and inflation, but increases in these two variables lead to reduced credit growth. The resulting feedback loop, therefore, might cause these effects to cancel out.

In Russia, one key finding is that increases in commodity prices lead to reductions in credit growth and commodity-price declines result in a credit expansion, most likely due to consumption-smoothing in the face of adverse shocks. Consumption increases to a greater extent after a positive shock to domestic credit. There is little evidence, therefore, of a drop in commodity prices leading to a "credit crunch" that reduces Russians' standard of living. As for the other macroeconomic variables, CRG and the Current Account have very small, brief (yet significant) effects on each other, which are opposite in sign. These effects, therefore, most likely cancel out, as an increase in domestic credit leads to a current-account surplus - which reduces credit growth. Increases in domestic credit cause the ruble to depreciate and GDP growth and inflation to increase. At the same time, inflation and GDP growth also reduce the growth rate of domestic credit, signifying another dampening effect.

In Ukraine, there are fewer significant responses. Commodity-price increases are shown to lead to credit expansions, but the effect is barely significant. As was the case with the Granger causality tests, the current account and consumption are relatively insulated from credit growth and other variables. Currency appreciations increase credit growth, while credit expansions lead to depreciation. Again, self-dampening effects register as insignificant when other tests are used. Credit growth is mainly linked to reduced inflation.

Belarus
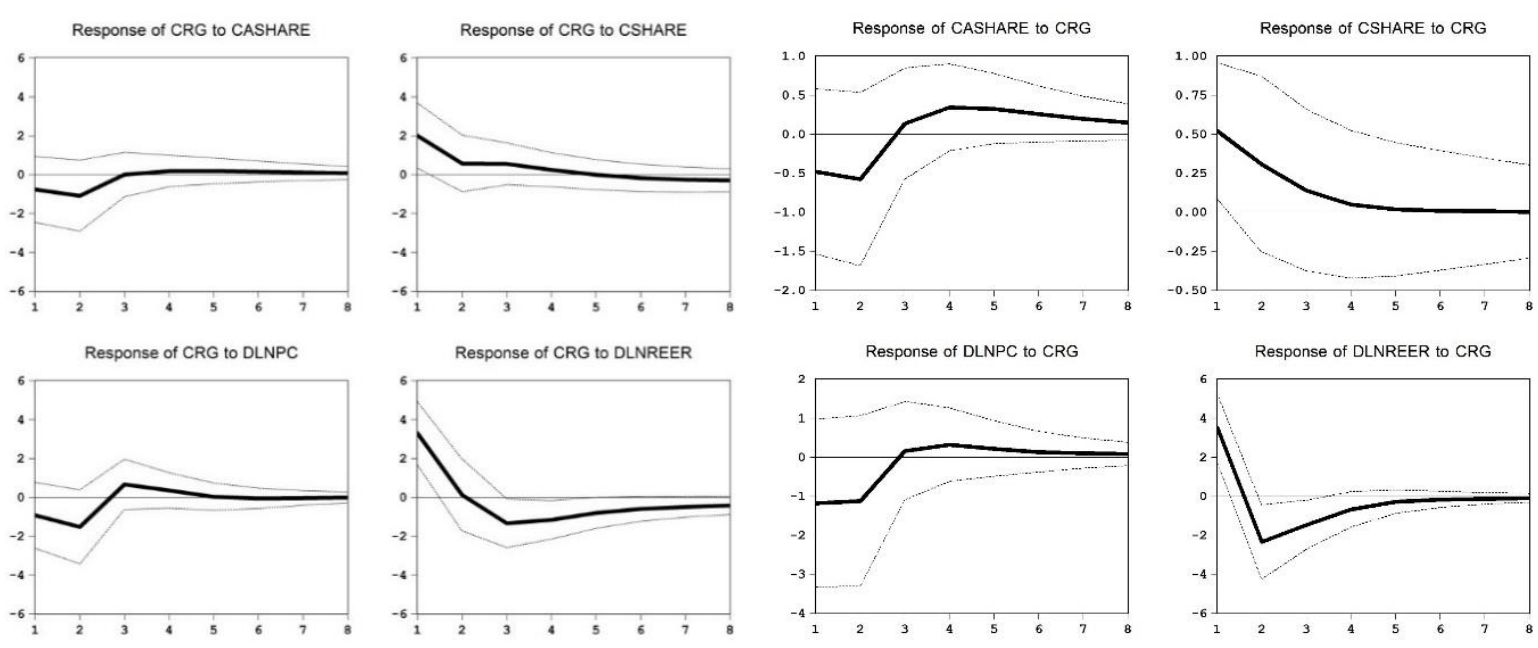

Response of CRG to GROWTH

Response of CRG to INF

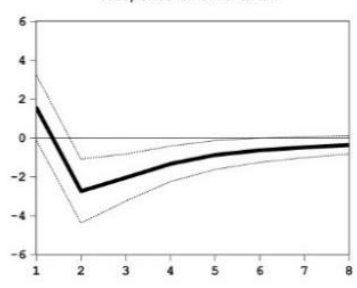

Response of GROWTH to CRG

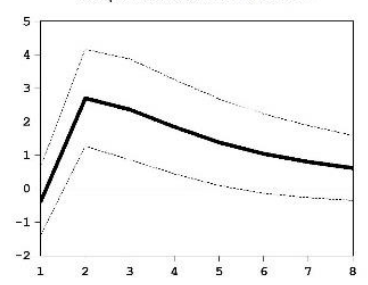

Response of INF to CRG

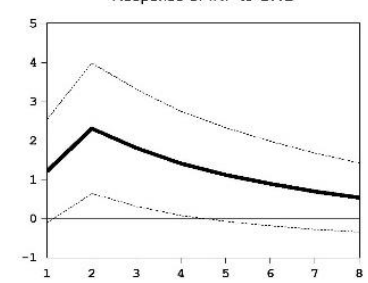


Russia
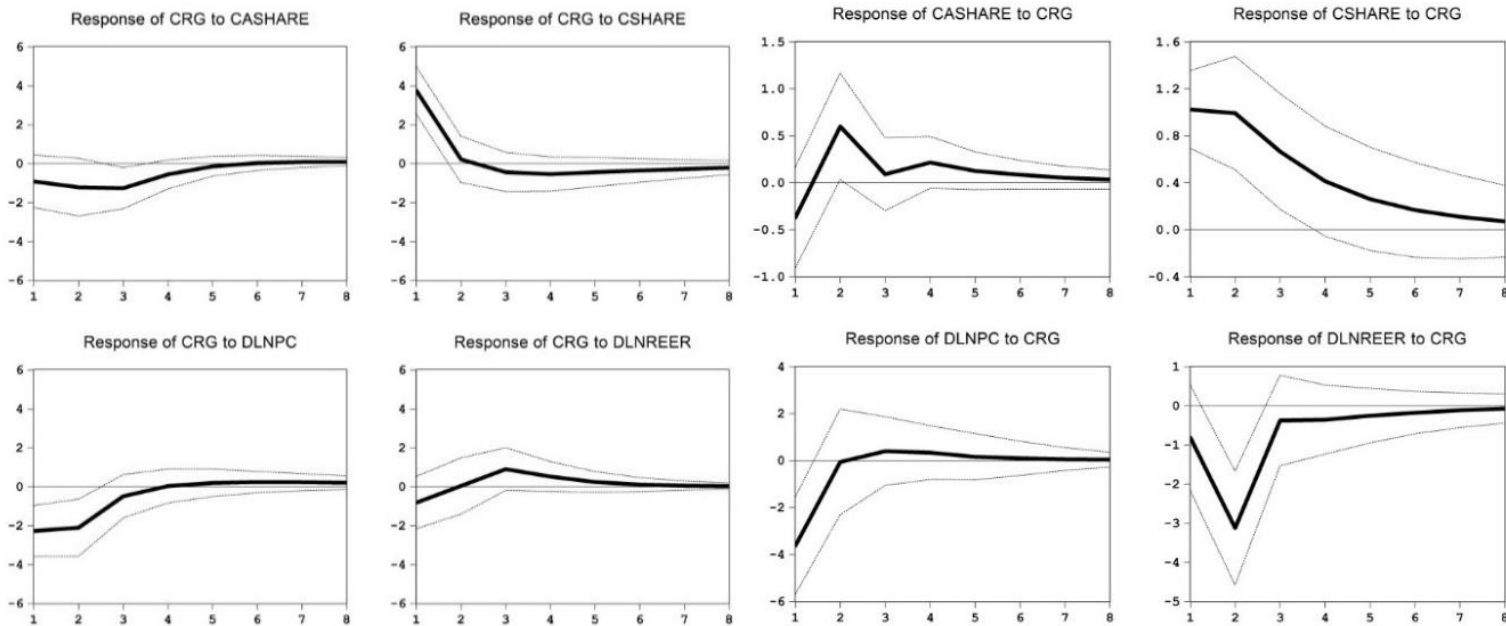

Response of DLNREER to CRG
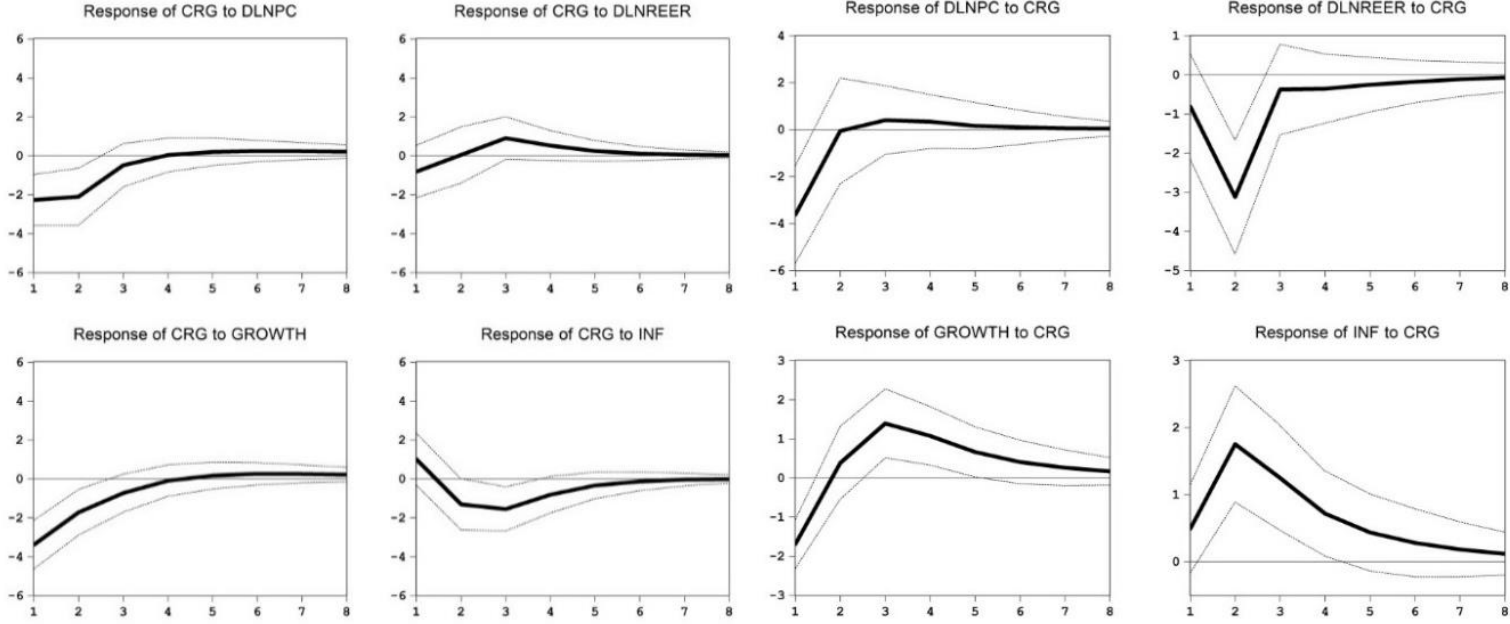

Ukraine

Response of CRG to CASHARE

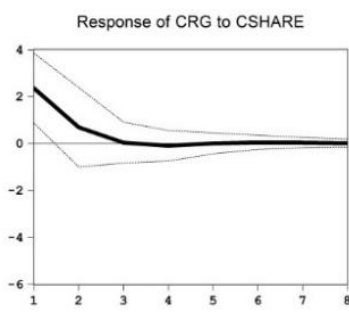

Response of CASHARE to CRC
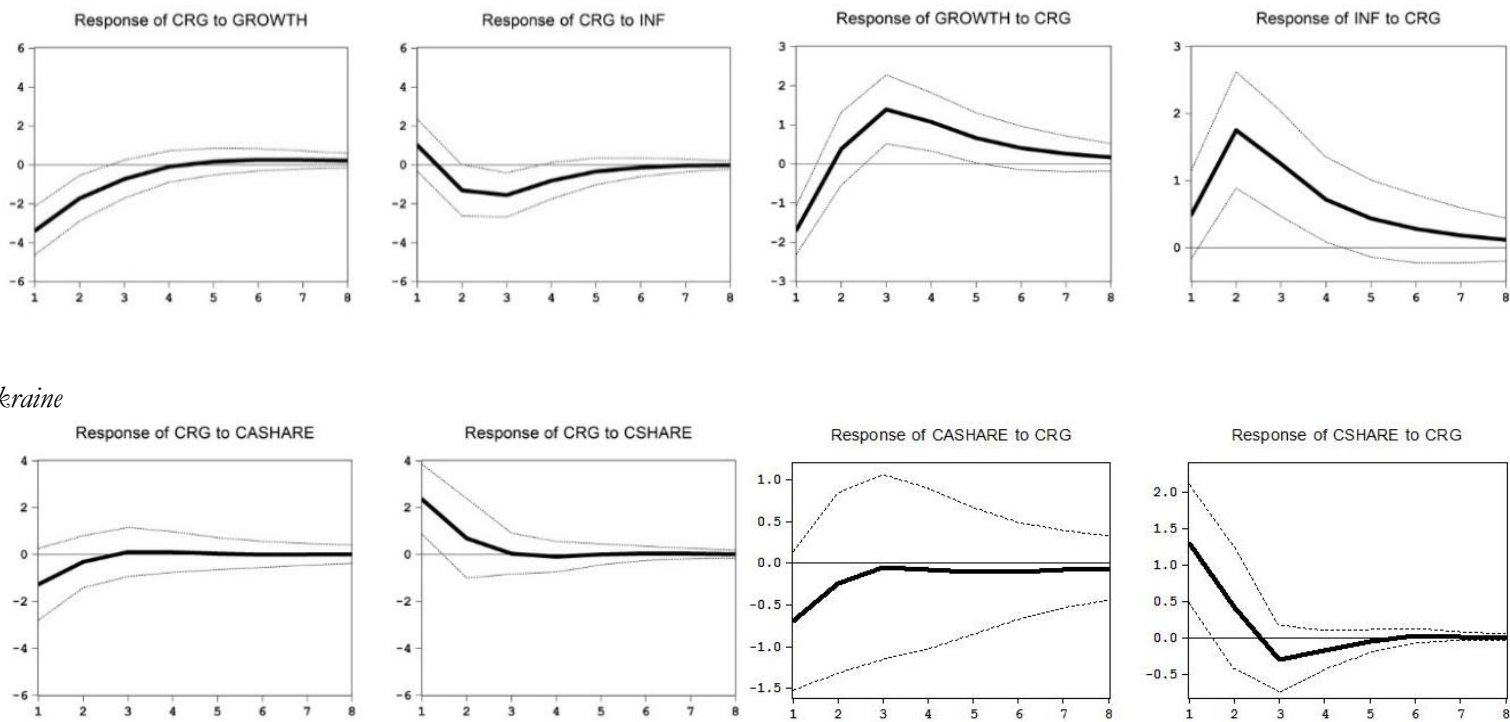

Response of CRG to DLNREER
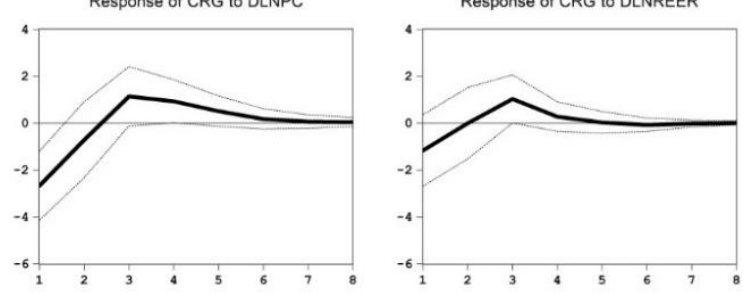

se of DLNPC to CRG

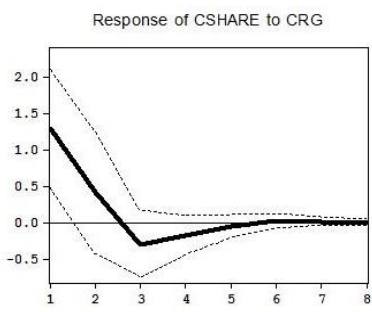

Response of CRG to GROWTH
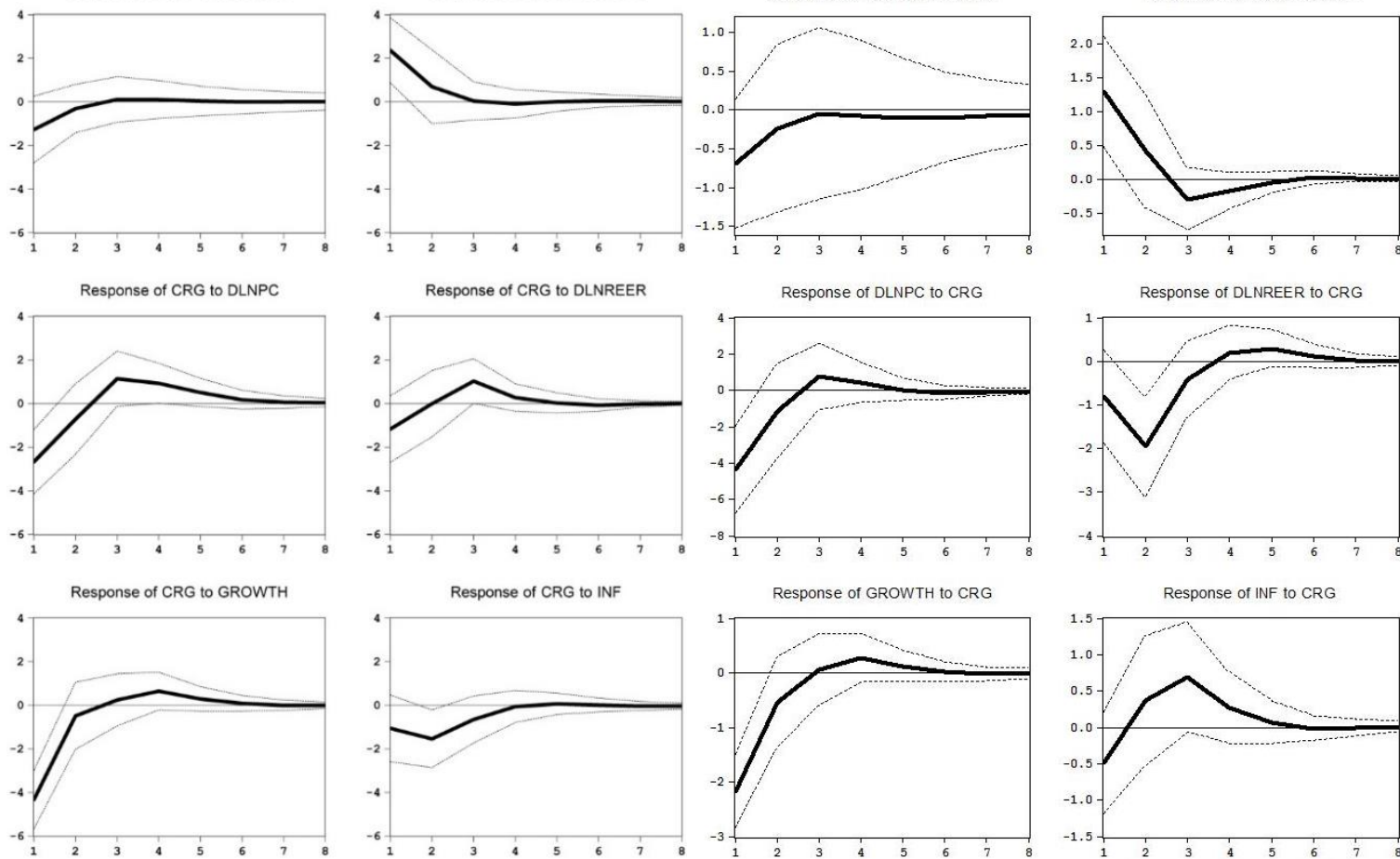

Response of GROWTH to CRG

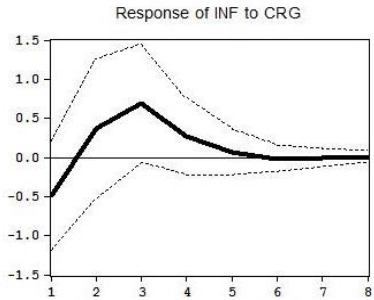

Figure 6. Generalized Impulse Response Functions ( \pm 2 Standard-Error Bands)

Note: Impulse Responses are considered to be "significant" if the 2-standard-error-bands are entirely above or below the zero line, for any period. Positive and negative effects are noted as well. The period at which this takes place is noted to assess the speed of response and adjustment. 
Overall, therefore, when the direction of variables and the signs of their significant effects are taken into account, they often cancel out in a way that matches the results of the Granger Causality tests. Consumption is rarely linked to domestic credit, in either direction of causality. Nevertheless, there is find evidence that domestic credit is driven not only by macroeconomic variables such as growth and inflation in all countries but that increases in commodity prices lead to decreased credit growth in Russia. In all countries, the link between inflation and credit growth is strongest in all countries, suggesting that credit expansion can be constrained if purchasing power is reduced.

\section{CONCLUSION}

While consumer credit has expanded rapidly throughout the region during the transition to capitalism, leading to increased consumption and higher standards of living, those countries that have joined the European Union typically have received more attention in the literature. Those EU countries were particularly vulnerable to large capital inflows prior to the 2008 financial crisis, leading to a credit "bubble" that has since collapsed. Russia, on the other hand, differs from its neighbours due to its status as a major oil exporter. It is, therefore, more vulnerable to fluctuations in the prices of oil and other commodities that are most EU countries. This study expands the literature by examining the experience of Russia, as well as its neighbours Belarus and Ukraine. Two time-series methods, cyclical correlations and VAR analysis, are used to examine the linkages among commodity prices, domestic credit growth, and household consumption for these three countries.

Overall, this study fails to find any connections between domestic credit and consumption, while commodity prices drive credit growth most strongly for Russia and least for Ukraine. While VAR methods are most robust in terms of describing the direction of causation, the results from the IRFs are often ambiguous because of a number of self-cancelling bidirectional relationships. The results of Granger causality tests, as well as the cross-correlation functions between pairs of filtered cycles, are therefore clearer in their presentations of important relationships.

Policymakers who wish to avoid any repeat of a "credit" bubble in this region would, therefore, benefit from paying attention to the connections between inflation and credit growth in all three countries, as well as the role of commodity prices in Belarus as well as Russia. If it is indeed the case that inflation constrains the growth of credit, it would be advisable to focus on maintaining purchasing power if credit is to grow at a healthy pace.

Credit growth might theoretically serve as an intermediate variable in a process where commodityprice fluctuations spill over to the real economy. From a political standpoint, policymakers should pay particular attention to the channels that link commodity prices, domestic credit, and consumption. These will likely differ between those countries that import energy and those that export energy. In that sense, then, Russia might be most vulnerable to a series of events by which oil prices decline, leading to a credit crunch that reduces consumption - which would put pressure on the government to improve living standards. But this "chain" is not proven by the evidence here. Instead, commodity-price declines lead to credit expansions in Russia, which help expand consumption to both maintain consumers' standards of living and to compensate for lost government revenue. While commodity-price movements do indeed affect credit growth, consumption is more insulated from credit growth in Ukraine and Belarus. Whether this persists is an open question. 


\section{REFERENCES}

Allegret J.-P., \& Sallenave, A. (2015). Capital flow bonanzas and monetary policy in Emerging Europe: Responses to the Global Financial Crisis. Post-Communist Economies, 27(4), 429-447.

Apostoaie, C.-M., Percic, S., Cocris, V., \& Chirles., D. (2014). Research on the credit cycle and business cycle with a focus on the ten states from Central, Eastern, and Southeastern Europe. Emerging Markets Finance \& Trade, 50(4), 63-77.

Backus, D.K., Kehoe, P.J., \& Kydland, F. E. (1992). International real business cycles. The Journal of Political Economy, 100(4), 745-775.

Carstensen, K., \& F. Toubal (2004). Foreign direct investment in Central and Eastern European Countries: A dynamic panel analysis. Journal of Comparative Economics, 32(1), 3-22.

Christiano, L.J., \& Fitzgerald, T.J. (1999). The bandpass filter. NBER Working Paper 7257.

Demekas, D.G., Horvath, B., Ribakova, E. \& Wu, Y. (2007). Foreign direct investment in European transition economies - The role of policies. Journal of Comparative Economics, 35(2), 369-86.

Égert, B., Backe, P., \& Zumer, T. (2007). Private-sector credit in Central and Eastern Europe: New (over)shooting stars?. Comparative Economic Studies, 49(2), 201-31.

Gibson, H.D. \& Tsakalotos, E. (2004). Capital flows and speculative attacks in the prospective EU member states. Economics of Transition. 12(3), 559-86.

Gueorguiev, N., Duenwald, C., \& Schaechter, A. (2005). Too much of a good thing? Credit booms in transition economies: The cases of Bulgaria, Romania, and Ukraine, IMF Working Papers: 05/128.

Hamilton, J.D. (2017). Why you should never use the Hodrick-Prescott filter. Department of Economics, UC San Diego, Working Paper.

Hegerty, S.W. (2009). Capital Inflows, exchange market pressure, and credit growth in four transition economies with fixed exchange rates. Economic Systems, 33(2), 155-167.

Hegerty, S.W. (2010). Central European business cycles: Might global (and local) linkages dominate regional ones? Eastern European Economics, 48(2), 56-73.

Hodrick, R., \& Prescott, E.C. (1997). Postwar U.S. business cycles: An empirical investigation. Journal of Money, Credit, and Banking, 29, 1-16.

Hoffmann, A. (2010). An overinvestment cycle in Central and Eastern Europe. Metroeconomica, 61(4), 711-734.

Kalyuzhnova Y, \& Nygaard C. (2009). Resource nationalism and credit growth in FSU countries. Energy Policy, 37(11), 4700-4710.

Kydland, F. E., \& Prescott, E.C. (1982). Time to build and aggregate fluctuations. Econometrica, 50,1345-70.

Lane, P.R. \& Milesi-Ferretti, G. M. (2007). Capital flows to Central and Eastern Europe. Emerging Markets Review, 8(2), 106-23.

Lane, P.R. \& Milesi-Ferretti, G.M. (2010). The cross-country incidence of the global crisis. IMF Economic Review advance online publication, 23 November 2010.

Lane, P.R. \& McQuade, P. (2014). Domestic credit growth and international capital flows. Scandinavian Journal of Economics, 116(1), 218-252

Lankes, H.-P. \& Venables, A.J. (1996). Foreign direct investment in economic transition: The changing pattern of investments. Economics of Transition, 4(2), 331-347.

Park, H. (2014). The comovements of capital inflows in the frequency domain: Evidence from emerging countries. Emerging Markets Finance \& Trade, 50(5), 148-158.

Pesaran, M.H., \& Shin, Y. (1998). Generalised impulse response analysis in linear multivariate models. Economics Letters, 58, 17-29.

Phillips, P.C.B. \& Perron, P. (1988). Testing for a unit root in time series regression. Biometrika, 75(2), 335-346.

Staehr, K. (2018) Capital flows and growth dynamics in Central and Eastern Europe. Post-Communist Economies, 30(1), $1-18$.

Vymyatnina, Y. V., \& Antonova, D. (2014). Credit booms in the countries of the Eurasian Economic Union. Are they related? Econometrics / Ekonometria, 3(45), 102-121. 